\title{
Chapter 10. The Founding of the House and the Source of Life: Two Complementary Origin Structures in Buru Society
}

\section{Barbara Dix Grimes}

On the eastern Indonesian island of Buru people express ideas about origin and cause with metaphors based on the imagery of a living plant or tree. The roots and trunk of a tree (lahin) and the young leaves which appear at the tips of the branches (luken) are the culturally significant points of reference for these metaphors. Many events, including sickness, litigations and warfare as well as simple narrations and tape recordings, are conceptually structured in terms of beginning at a "root" (lahin) and having "young leaf tips" (luken) as their end result or consequence. As they say on Buru, things progress "from the root until emerging at the tips" (fi di lahin eta suba luken). ${ }^{\text {I }}$

These epistomological metaphors are applied to many things in Buru. This paper focuses specifically on how these metaphors and ideas about origin are applied to people in the context of social groups in Buru society. Two types of conceptual structures of origin are discussed. The first concerns noro, the primary Buru social groups, which are defined by the unique ways in which they were founded, and by males who remain in them throughout their lives. The second concerns life which has a separate origin structure and is transmitted through females, giving individuals unique sources of life. In complementing each other, these two origin structures are the foundation for the construction of social relations on Buru.

\section{An Overview of Buru}

The island of Buru is approximately 140 kilometres east to west and 90 kilometres north to south. It is the third largest island in the Indonesian province of Maluku, second in size only to Seram and Halmahera. Just 110 kilometres of Banda Sea separate Buru from the provincial capital on the island of Ambon, but despite its geographical proximity Buru has historically been on the periphery of much that has occurred in the regional context. Having no native clove or nutmeg trees, Buru was of little importance to the spice trade which brought Asians and Europeans to other islands in Maluku as early as the fifteenth and sixteenth centuries. Not only did the boats of the spice trade by-pass Buru, much of the foreign contact that came to the region did as well (Map 1). 


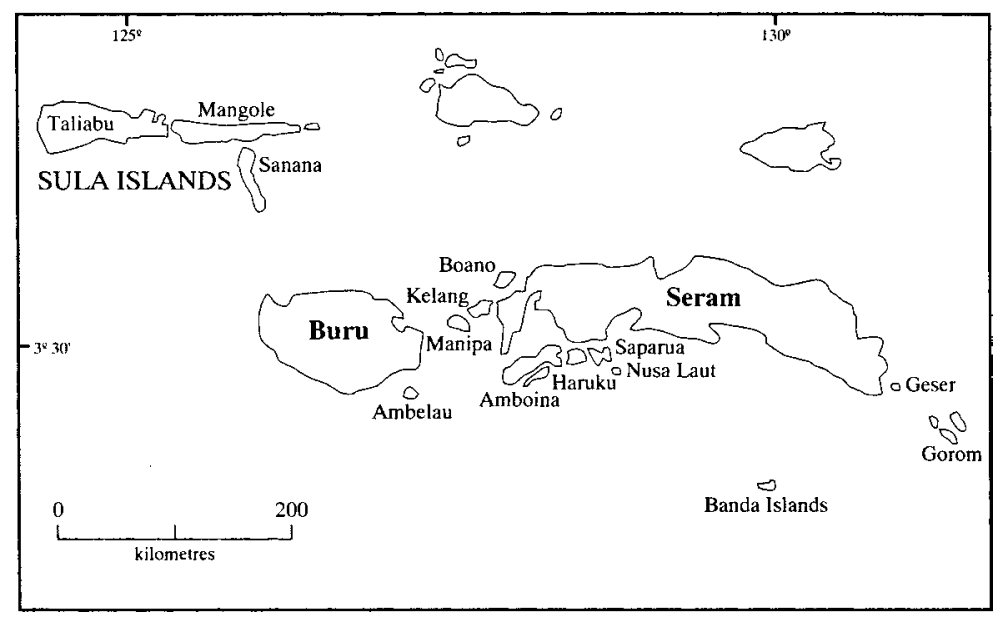

Map 1. Central Maluku.

Approximately 43,000 people consider themselves "people of Buru island" (geb fuku Bururo) and although they freely acknowledge some dialectal differences, they insist on being considered a cohesive linguistic and ethnic group belonging to this relatively large island by virtue of their origins. It is significant that the geb fuku Bururo comprise less than half the total population of 102,000 inhabitants on the island. Thousands of immigrants, particularly from the islands of Buton and Sula, have colonized the north and west coasts of Buru. Many of these colonies have been on Buru for several centuries and still regard themselves as ethnically distinct from Buru people and often continue speaking the languages of the islands from which they originated. Recently around 23,000 more people have come to the island, some brought initially as political prisoners after the 1965 political upheaval in Indonesia and others later as transmigrants. This predominantly Javanese influx has been localized on the island and almost without exception, all the immigrants on the island - longterm residents as well as recent arrivals - reside along the coast or on a few flat plains areas near the coast.

The interior of Buru is very mountainous, covered with dense jungle. Geb fuk Bururo often prefer to live in the mountainous jungle of the interior, rather than on the coast. The island of Buru can thus be characterized as having an indigenous minority population which is traditionally-oriented to the vast interior of the island while numerous colonies of immigrants from other parts of the archipelago fringe the coastal regions. The majority of immigrants on Buru are Moslem as well as a portion of the geb fuk Bururo now living on the coast. In the interior of the island geb fuk Bururo practice both Christianity and their traditional religious beliefs. ${ }^{2}$ 
The daily activities of geb fuk Bururo living in the interior of the island centre around gardening and hunting. Extensive hunting is done by men for wild pig, deer, cuscus and other small animals. Gardens are made, often on steep mountainsides, and shifting cultivation focuses around yams, cassava, and taro with smaller amounts of millet, dry rice and corn also grown. Where the terrain is suitable, sago is planted and cultivated. Considerable labour is necessary for gardening, particularly for opening new gardens in the jungle and for harvesting. During these long labour-intensive periods, people often live in their isolated garden huts scattered across the mountains. They may also have a house in a village but as it may be many hours' walk away from their gardens they return to live in the village only when the garden work temporarily permits them to do so. When fully inhabited, interior villages consist of 50 to 200 people living in 10 to 30 households.

Hunting and gardening is the responsibility of each household which typically includes a man, his wife or wives and their unmarried children. The individuals in each household are incorporated into higher level social groups called hum lolin and noro. A hum lolin, which literally means "house-circle", consists typically of agnatic kin related over four or five generations. In this paper I refer to hum lolin both by the Buru term and by "House", as it is a social group conceptualized in terms of a house metaphor. The genealogical connections between all the members of a hum lolin are known, and kin terms are used to refer to everyone within an ego's hum lolin. Leadership of a House is invested in geb emtuato meaning "old people", a term used to refer to parents and what approximates the English term "elders". In a political sense, geb emtuato are men who function in decision-making and negotiations as representatives of their House, particularly in matters concerning land and marriage.

Several hum lolin together comprise a noro. The relationship between a noro and its separate Houses is expressed as a whole which has broken into sections, using the term ekfakak meaning "to be broken into pieces". Each House has a "founding father" (tama) and "founding mother" (tina) who were the first to establish the House as separate from other Houses in the noro. Same sex sibling terms of relative age (kai "elder"/wai "younger") are used to describe the relationship between the various Houses within a noro.

A noro is the highest level social or political structure in Buru society and the total geb fuk Bururo population is divided into over 35 noro. No centralized political hierarchy unifies the different noro on the island and the situation, as they say, is one where "each noro governs its own noro" (noro saa printa tu nake noro). Marriages must be transacted between Houses of different noro. What defines Buru society as a whole is not any overarching political order, but networks of inter-noro relationships which can be characterized as much by alliance and marriage as by hostility and warfare. Although there may be less 
inter-noro warfare today than in the past, marriage alliances do not preclude warfare between noro and the threat of hostility from people of other noro is always considered present.

Before considering how the identity of Buru Houses and noro are articulated in terms of their origin structure, it is necessary to first discuss how individuals become affiliated with these social groups. Marriage and bridewealth are very important aspects of affiliation on Buru. Upon marriage, men "stay in the house to guard the sharpening stone" while women "exit" (suba) their natal House to "return" (oli) to the House and noro of their husband. Marriage thus transfers a woman to another House and noro, and hopefully results, through her fecundity, in the increase of her husband's House. Because of this, marriage is very much the concern of the hum lolin. When a "son" of a hum lolin is to marry, it is the responsibility of the entire hum lolin to contribute to the bridewealth, part of which goes to the actual parents of the bride and part to her hum lolin elders.

After a woman marries, children born to her belong to the House and noro of her husband. While it may in effect appear as if the father-child link is the important criterion, affiliation to Buru social groups is not constructed in terms of such links. ${ }^{3}$ People on Buru formulate their ideas about the affiliation of children in terms of "child rights" (hak anat) which are transferred in the marriage process from a woman's natal hum lolin to the hum lolin of her husband in a different noro. The affiliation of children is thus intricately tied to the marriage process. It is only after the bride's House has received some form of "compensation" (filin) for their loss of the bride and the final stages of the marriage process have occurred, that hak anat is transferred to the House and noro of a woman's husband. Before marriage negotiations for a particular woman have been initiated, hak anat belongs to her natal hum lolin. Any children born to her before she is married belong to her natal hum lolin and noro, the noro of her brother, who is under those circumstances called her child's "father" (ama).

In many cases bridewealth is given to replace the bride and bridewealth becomes an important indicator that hak anat has been transferred. Then, as they say on Buru, bridewealth should "bear fruit". That is, bridewealth should result in the increase of members in the House. This idea is expressed in a number of different ways. When a woman is barren, her bridewealth is said to have borne no fruit and the collection of it by her husband's House is considered to have been wasted effort. If a young bride dies before she has given birth to a child, her natal House is obligated to replace her with another bride, because the bridewealth has not yet borne fruit. However, if a bride dies after giving birth to a child, it is not necessary for her natal hum lolin to replace her. If the child she has borne is a son, the bridewealth has borne fruit and her husband's House has increased. If she has borne a daughter, the daughter will eventually "return her mother's bridewealth" to the hum lolin when she marries. Beside 
bridewealth, there are other ways to replace a bride. A child can be given to the bride's House or sister-exchange can take place. Whether it is by bridewealth, a child, or another bride, when the bride has been replaced, the affiliation of her future children belong to the House and noro of her husband.

\section{The Founding of the House}

Fox has noted there are various social groups in societies throughout eastern Indonesia which can be characterized by what he calls origin groups in that:

... what they claim to share and to celebrate is some form of common derivation. This derivation is socially constructed and may be variously based on the acknowledgement of a common ancestor, a common cult, a common name or set of names, a common place of derivation, and/or a share in a common collection of sacred artefacts (this volume:132).

The Buru noro, composed of Houses, is such a social group, sharing and celebrating a common origin. In this section I describe the configuration of ideas which make up the "origin structure" of a Buru noro. ${ }^{4}$

Most important in the origin structure of each noro is a moyang. For convenience I gloss this Buru term as "founding ancestor" but it is important to understand how Buru people use the term as there are some significant semantic differences between the Buru meaning of moyang and the English meaning of "ancestor", as well as between the Buru meaning and the standard Malay or Indonesian meaning of the same form which is in more ways like that of the English term "ancestor". The English term is based on genealogical criteria and denotes a person at the apex of a genealogical relationship (Keesing 1975:21). On Buru, genealogical links to individuals in the past are recognized (enohon enatin), and can be important at times, but genealogical links are not the basis for an individual's relationship with his moyang. It is an individual's affiliation to a particular noro that determines his or her particular moyang.

Moyang are culturally significant for many reasons, one of which is that they are potentially involved in the everyday affairs of living noro members. There are numerous cases on Buru where people change their noro affiliation and "enter" (rogo) a new noro. This occurs most frequently with women through marriage, but there are also various kinds of adoption (cf. B.D. Grimes 1990). When people change their noro affiliation for whatever reason, they acquire the moyang of their new noro who can be pleased or displeased with the conduct of their newly affiliated offspring.

As spirits who have the potential for both blessing and punishing their living noro offspring, moyang are in some ways similar to the spirits of dead noro members (nitu) who can also bless or curse their living kin. And yet moyang and nitu are very different. Nitu are the spirits of very normal humans who have 
died relatively recently, while moyang were physically present on earth in the remote past, in the founding time of society.

In attempting to grapple with Lao categories of spirits in Fiji, Hocart noted that a class of spirits called $v u$ (which he also referred to as "gods") had as their chief characteristic "originating". He also noted "the Fijians are very careful to distinguish between the spirits of the dead and these [vu] gods" (1952:9). While admitting the difficulty of finding an adequate gloss for $v u$, Hocart referred to them as "founder-gods". The Buru concept of moyang has many similar features. The chief characteristic of moyang is that they each founded a noro which later divided into various Houses. There are no moyang who are not originators. At the same time, moyang have semi-divine characteristics in that they were not ordinary humans. As founders of society they are known to have performed supernatural deeds having more power than is associated with normal humans.

So while all moyang are founders of noro, each moyang is considered to be unique and to have founded a unique noro. Differentiation is constructed among moyang in several ways, including gender, how they came to be on Buru, and where they became established on Buru. The first of these criteria establishes a moyang as either male or female which may be specified as "father founding ancestor" (ama moyang) or "mother founding ancestor" (ina moyang). While the gender of a specific founding ancestor is always known, there is no social differentiation made between noro on the basis of the gender of their founding ancestor, nor is there any difference in the affiliation rules between noro with male or female founding ancestors.

The second way in which moyang are differentiated is in the manner associated with their appearance on Buru. The founding ancestors of some noro are autochthons who "appeared" (newa) at the headwaters of streams on the island, while the founding ancestors of other noro came to Buru by boat from other islands. This is the case for example with the founding ancestress of the Mual noro, Bokis Raja, who came from the Hoamoal peninsula on Seram to Buru.

Thirdly, each moyang is associated with a unique place on Buru, giving each noro a place of origin. The place where the moyang was first established on the island is called the tean elen which literally means the "place of the planted house pole". The tean elen of autochthonous moyang is at the specific spring or stream in the mountains where the moyang appeared. The tean elen of a noro with non-autochthonous moyang is the place where the moyang first went after arriving on the island by boat: the stream or river they came to and subsequently planted a house pole. The name of the stream at which a moyang established itself is often given to the noro and referred to as the "ancestral water/stream" (wae moyang) of that particular noro. There is an additional place on the coast associated with non-autochthonous moyang: the place of the "boat disembarkation" (waga enohon). 
There are ties to this place as well as to the "place of the planted house pole" and the "ancestral stream", associations of the journey and power of the moyang.

There is a well defined and often large territorial area surrounding the place of origin which belongs to the noro and is divided into portions belonging to each hum lolin. Land rights and hunting rights to the territory are inherited by Houses, and people of other groups must request permission to make gardens or to hunt there. Today there is a far from perfect correlation between the places where people currently reside and their places and territories of origin because of frequent migrations to other parts of the island. Mass sickness and death are the most frequent reasons given for such migrations, some of which have brought people to live at places on the island far from their original tean elen. The important point is that even if people no longer live in their original territory, they still inherit this land and they still control rights to its use because it is part of the origin structure of the House and noro to which they belong.

Near or at the tean elen is a hum sikit or house in which its various heirlooms are stored. Heirlooms typically include ruling cloths, staffs and other objects of noro history. Because migrations have been so frequent and people do not live near their tean elen, these houses have been difficult to keep up. In actual fact, many noro have not had a hum sikit for many years. Hum sikit are never the focus of much activity and many people are rarely at their tean elen, but the idea that each noro should have a hum sikit in which to store the objects of its history is still present on Buru.

Around 1990 one noro rebuilt their hum sikit near their tean elen far in the interior of the island. This involved carrying metal roofing up the mountain several days' walk to use in the construction. This innovation was not missed by other noro in the area and they also began discussing how to collect money to buy roofing and then construct a "modern" hum sikit for their own noro. The value of metal roofing is in very practical terms the fact that it will outlast thatch roofing for many years and make the hum sikit last many more years before repairs are needed.

The origin structure of a Buru noro also includes names for the noro as well as its Houses. A hum lolin is frequently named after a prominent geographical feature such as a river, stream, tree or rock near the garden house of the "founding father of the House" (tama). Names for noro come from a variety of sources. Sometimes the name of the founding ancestor is reflected in the name. Another naming strategy already mentioned is to make use of the origin place name. The "ancestral stream" (wae moyang) of the Wae Temun noro is a small stream called Wae Temun. The Wa Kolo noro has its origin place at Wa Kolo, an alternate name for the lake (Rana) in the centre of the island.

Each noro has two names: an "inside" name and an "outside" name. The inside name is referred to as the noro name and the outside name is called the 
fam ${ }^{5}$ name or the "Indonesian name". The outside name is used much like a surname when people interact with the Indonesian state, such as when enrolling their children in school, signing legal documents and so on. Non-Buru immigrants and other outsiders are said to only have an outside ( $\mathrm{fam}$ ) name. Because the origin structure of a Buru noro includes both inside and outside names, the lack of an inside name is seen as evidence that these people lack a Buru origin structure and therefore cannot be "people of Buru island" (geb fuk Bururo).

The origin structure of a noro thus includes a founding ancestor, a place of origin called the tean elen where ideally a hum sikit is maintained for storing heirlooms, a traditional territory belonging to each House, and inside and outside names. These origins are not just seen as facts of history, but are relevant to everyday life. People may seek the help and blessing of their moyang in any place, but it is always much more efficacious to ask for blessing at the tean elen. This ideology results in one of the many ways in which people on Buru strive to return to their origins for blessing. If it is deemed necessary, people who have moved away will spend much time, money and effort to return to their tean elen to seek the blessing of their moyang.

The uniqueness of each noro and House is constructed in terms of differences in the salient features of their origin structures. Equally significant, Buru ideas about social hierarchy and equality are also articulated in terms of these origins. In discussing hierarchy in eastern Indonesia, Fox has noted hierarchy is both structured and countered through the use of dual categories. When dual categories structure hierarchy he states:

The hierarchical use of dual categories depends upon the conjunction of two analytic features: recursive complementarity and categorical asymmetry (1989:59).

These two analytic features can be illustrated at precisely the place where hierarchy occurs in Buru society: at the ranking of Houses within a noro and the ranking of same sex siblings within a House. In these cases hierarchy is constructed through the use of the complementary dual categories of elder-younger same-sex sibling terms. These categories are asymmetrical in that the superiority of the elder is always stressed on Buru and reflected in statements such as "an elder [same-sex sibling] (kai) will always be an elder [same-sex sibling] (kai) and must always be treated as such". These asymmetrical categories are then applied recursively to produce precedence within the noro and House. 


\begin{tabular}{|llll|}
\hline elder & $\begin{array}{l}\text { younger } \\
\text { elder }\end{array}$ & $\begin{array}{l}\text { younger } \\
\text { elder }\end{array}$ & $\begin{array}{l}\text { younger } \\
\text { elder }\end{array}$ \\
& & younger \\
\hline
\end{tabular}

Precedence within a House and noro.

This ranking or precedence is fixed. Within a House, it is fixed among same-sex individuals according to the timing of their relative births. Within a noro, it is fixed among Houses according to the timing of their relative establishments. This is often geographically objectified in that a noro is associated with a particular river or stream and the origin place of each House along the river system is known. Elder Houses were always established first, closer to the source of the river and therefore upstream to younger Houses. Precedence thus flows from elder to younger, from upstream to downstream, from the headwaters in the mountains at the centre of the island to the periphery of the island at the coast.

Turning from internal relationships within a noro where precedence is established between Houses and individuals, to external relationships between noro, categorical asymmetry is no longer found. Dual categories exist in the classification of noro, just as they exist in the classification of Houses and individuals, but this time no asymmetrical value is assigned. People in every noro express profound respect for and stress the uniqueness and power associated with their particular founding ancestor, but none of the differences among founding ancestors - their maleness or femaleness, their autochthonous or non-autochthonous origins, their order of appearance - translates into categorical asymmetry. Reflecting the classification of their moyang, people can be called "original people" (geba dengen) or "people who arrived" (geba enadut), but again superior value is assigned to neither category. Difference is constructed, but it does not produce precedence or rank.

This construction of difference and the assignment and non-assignment of superior value to the resulting categories formulates the nature of social relationships on Buru. Within the noro, House relationships are both inalterable and hierarchical. Similarly, within a House every individual knows his or her place in the ranking of generations and the ranking of elder and younger samesex siblings. Of only one person and one House can it be said "There is no one elder."

Between noro, however, where there is no established precedence, it is possible to avoid relationships of asymmetry. The ideology of "a person replaces a person" (geba gati geba) is the primary operating principle in inter-noro relations and applies equally to the loss of women in marriage as it does to the loss of men in warfare. In warfare "revenge killing" (kalungan) demands that there be an equal number of deaths between two noro. In marriage, the cultural option of 
"reciprocally exchanged maidens" (emhuka eptukar) allows for the simultaneous exchange of women between two groups. This makes the two noro and Houses simultaneously both "wife-givers" (kori) and "wife-takers" (sanat) to each other and makes two men simultaneously both WB and ZH to each other.

Symmetrical marriage exchanges can occur between two groups at a single point in time through emhuka eptukar, but they also occur over time through the accumulation of bi-directional single marriages. Arrangements involving the marriage of only one bride always necessitates the asymmetry of kori over sanat and of the WB over his $\mathrm{ZH}$ in the context of that particular marriage. However, the cumulative effect of bi-directional marriages between noro - both single marriages and emhuka eptukar marriages - allows two noro to see their overall relationship as one of symmetry. Positive relationship between two noro is equated with the symmetry that occurs when "they are WB and $\mathrm{ZH}$ to each other" ( $d u$ wali-dawen). The relationship between men who are "reciprocally both WB and ZH to each other" (wali-tal-dawet) exemplifies Buru ideals of the intimate friendship and equality that can exist between men and social groups in symmetrical relationships.

It is thus the assignment and non-assignment of value to features in the origin structure of noro and Houses that formulates the context for social relations on Buru. There is a perpetual deference to the hierarchy of elders within a House and noro and at the same time a continual striving for equality in relationships with other noro. Hierarchy within the House and noro is fixed and permanent, while equality between noro must continually be achieved and maintained.

\section{The Source of Life}

The way in which people on Buru conceptualize their ideas about the source or origin of life is reflected in certain kin terms which are listed in the following table.

\begin{tabular}{|ll|}
\hline yoi & FZ \\
wate & FZH \\
mate-lahin & $\mathrm{MB}$ \\
emdaa & MBW \\
wali lahin & $\mathrm{MBD}$ (m.s. and f.s.)/FZC (f.s.) \\
naha lahin & MBS (m.s.) \\
wali ennewet & MBS (f.s.) \\
feta ennewet & FZS (m.s.) \\
ana ennewet & FZD (m.s.) \\
wate & ZC (m.s.) \\
\hline
\end{tabular}


Selected Buru terms for kin in other noro.

${ }^{a}$ Throughout this paper I gloss mem-lahin as MB for the sake of convenience, but on Buru the genealogical relationship is not the only criterion. While a mem-lahin is genealogically $\mathrm{MB}$, he must belong to another noro. In other words, ego's mother must be married. If ego's mother is not married, his or her genealogical MB is called ama (father) as they belong to the same House. Mem-lahin, as I was told, is a term which has to have "two noro". I similarly gloss the other terms here with genealogical relationships, but they all include the obligatory social fact of being relationships between individuals in different noro.

Many of these terms are based on the epistomological metaphors of the living tree mentioned at the beginning of this paper. In these cases, the terms are compounds, composed of a kin term plus a metaphor as a modifier. The kin terms upon which the compounds are based include:

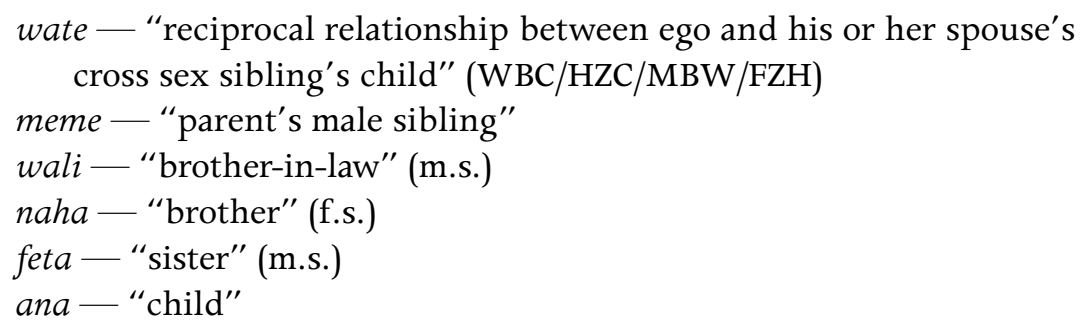

The two modifiers are lahin ("root/trunk") and ennewet ("life"). The compound terms can thus be given more specific glosses as follows:

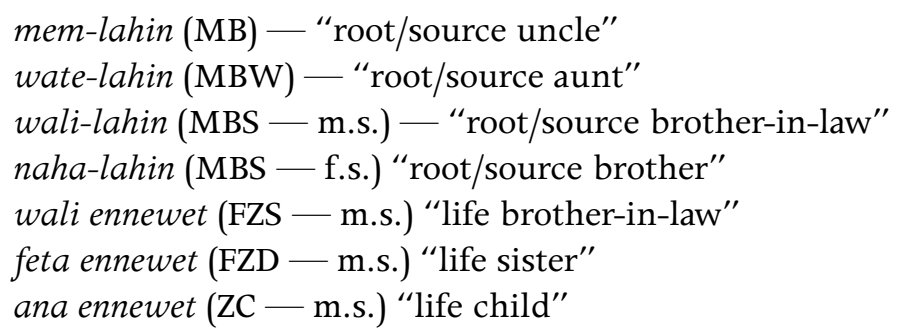

A girl and boy who are reciprocally emdaa (MBD/FZS) are in an avoidance relationship as they are both potential and ideal marriage partners. Children are told "Play with your elder and younger siblings; don't play with your emdaa." People have told me that a boy could call his MBD feta lahin ("root/source sister") and a girl could equally call her FZS naha ennewet ("life brother") but this is not necessary, as they are emdaa and that term is preferred. While these additional terms are seldom used, as equivalents they point out the consistency in the structure of the kin terminology for the descendants of a brother and sister. Relatives traced through a mother's brother are described as lahin kin while those traced through a man's sister are ennewet kin. 


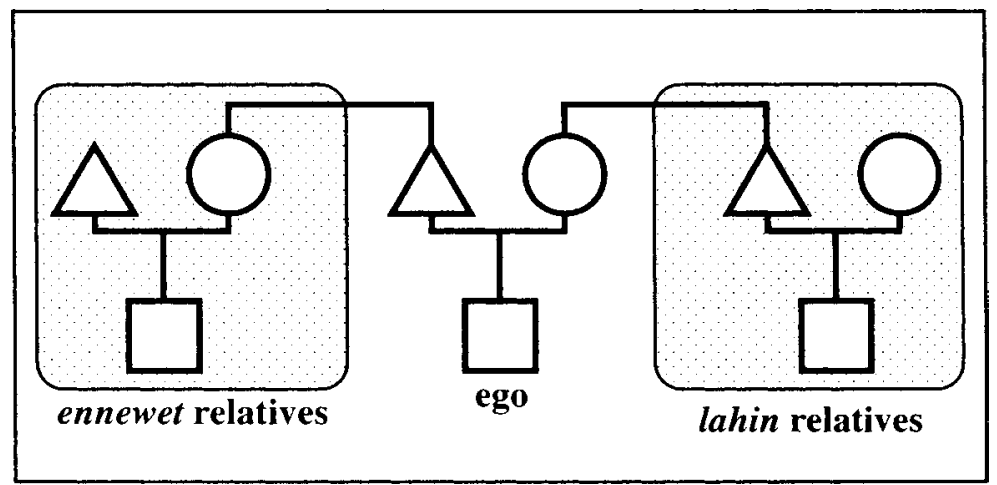

Figure 1. Life (-ennewet) and source (-lahin) relatives.

Concepts of source and life are thus used to express the relationship between the offspring of a brother and sister, and even more significantly, between a man and his sister children, a "source uncle" (mem-lahin) and his "life children" (ana ennewet). While these metaphors were mentioned earlier, it is helpful to consider them in more detail here. If someone on Buru were asked to point out a lahin, it would be a "wood-lahin" (kau lahin) which would include the main trunk of a tree, the base of the tree and its major roots. A typical kau lahin would be a tree with a tall single trunk such as a "coconut tree" (niwe lahin), "sago tree" (bia lahin), or "canarium tree" (ipa lahin). Based on the imagery of the life-producing roots and trunk of tall trees, lahin is an ideal metaphor to express a cultural concept of causality which sees subsequent events as stemming from an origin, cause, foundation, beginning or source.

The counterpart to lahin is luken which refers to the tiny new leaves that grow off the tips of branches, as in mangkau luken, the young new leaves picked to eat from the top of the cassava plant. As a continuation of the botanical imagery, luken is metaphorically used to refer to the tip, the end, the results, or the ramifications of someone's deeds, and not surprisingly, to someone's "descendants". Anyone who reckons his genealogical connections to an important person in the past will proudly tell you "I am a tip from him" (Ya puna luken fi di rine). Buru ideas about personal origins are thus turned upside down to European ideas about "descent", a point which Fox (1988) has noted as occurring in many eastern Indonesian societies. While Europeans talk about "descendants" in reference to someone's CCC, on Buru people talk about CCC as luken "ascendants" or "tips". The social unit of the hum lolin, as another example, can be described as the "tips" of the "founding father" (tama).

The Buru idea being expressed in the kinship terminology is that life has a source. Life comes from females giving birth to children. Because a woman changes her affiliation and "enters" (rogo) her husband's noro and House when she marries, her brother represents the source or origin of her children's life. 
He is thus their "source uncle" and they his "life children". Botanically life in the young leaf tips comes from the root. Metaphorically this is true of humans as well and is reflected in the statement of one old man who proudly told me he had "young leaf tips of life children" (ana newe luken) all over the mountains of south Buru.

The relationship between source and life is also reflected in the cultural responsibilities assigned to a "source uncle" in regard to his "life children". A man is responsible for the life of his sister's children. He is ritually responsible to ensure the fertility of his sister, that her children do not die at birth, and that appropriate marriages are arranged for them. A child is taught to respect his mem-lahin and the curse of sickness and bad fate hangs over anyone who does not obey their mem-lahin. A mem-lahin is not responsible for the sustenance of his ana ennewet, however. That is the responsibility of his sister's husband, hum lolin, noro, and ancestors.

So while a man's "life children" do not belong to his House or noro, he is responsible both for the transmission of life to them and through them. Because of this he plays an important role not only when they are infants, but also in selecting marriage partners for his "life children". The best way to ensure numerous and healthy children as the result of a marriage is for a man to return to the group which represents his own source of life and seek as a wife either his actual emdaa (MBD) or someone from another House in his mother's natal noro. If the mem-lahin has a marriageable daughter he has the prerogative to say to his sister and her husband "cause your child to become [my] son-in-law" (pemsawan nim anat) and so a boy's mem-lahin (MB) becomes his ama kete (WF). If his sister's son does not marry his daughter, the mem-lahin must be the one to "give the machete to cut open the path for marrying someone else" (duwe todo la sasa tohon la ketik geba meget). The mem-lahin then acts as one of the spokesmen in the marriage negotiations of his ZS as well as his ZD. Marriage is thus another case where Buru ideas about returning to one's source are enacted.

Sources of life are kept track of for two generations on Buru. Two terms, mara and halan, are used specifically to define relationships of individuals to other noro through which they trace their source of life. Mara refers to the noro of an ego's mem-lahin and halan is the noro of an ego's mem-lahin's mem-lahin (MBMB). These connections are illustrated below: 


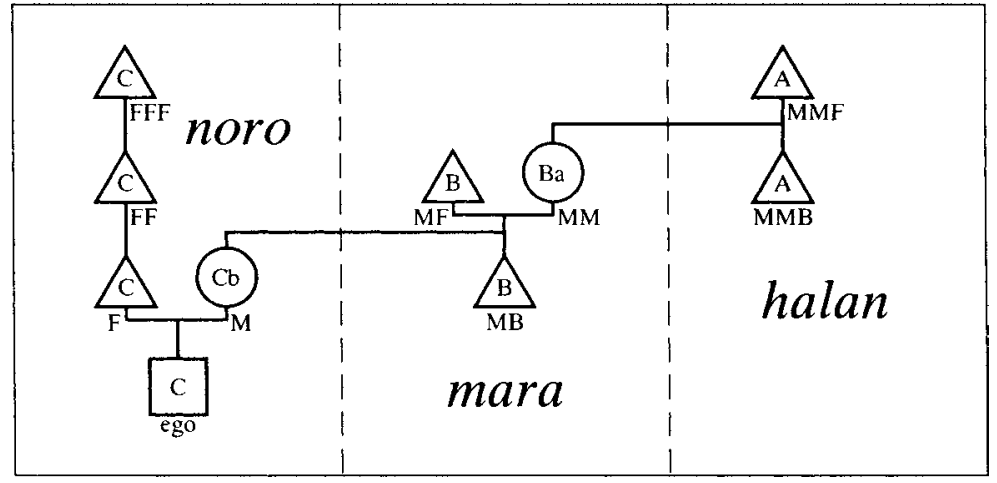

Figure 2. Mara and halan: reckoning maternal noro as the source of life.

At birth, individuals are affiliated with their natal noro but trace their origin of life through female connections to their mara and halan. The ties to these two other noro do not diminish an individual's membership in his own noro, but are the recognition of his source of life. On the basis of these ties he can request hunting rights or permission to build gardens in the land of his mara or halan. And most importantly, it is to his mara or halan that he should return when seeking to marry and propagate new life.

\section{Conclusion}

In this paper I have discussed two cultural concepts constructed around ideas of origin and source in Buru society. The noro is a social group composed of Houses defined by males who stay in them. These groups celebrate a unique founding and have an origin structure which includes a founding ancestor, a "place where the house pole was planted", heirlooms, a house in which to store them, an inherited territory and inside and outside names. Hierarchy and equality in Buru society is formulated based on value assigned to features of origin structures. Where asymmetrical value has been culturally assigned, precedence is given to elder Houses within a noro, for they were established prior and upstream to younger Houses, and to elders within a House, for they were born before juniors. Between noro, however, there is no asymmetrical value assigned to origin structures. Consequently, there is no established precedence and the possibility of equality exists in relationships with other noro.

There is also an origin structure associated with life, based on the metaphor of tall standing trees where life in the young leaf tips comes from the root and trunk. Women produce life and the source of a child's life is in his mother's natal noro and House. Because women marry and change their affiliation as they "exit" and "enter" Houses of different noro, the source of their children's life is represented by their brothers. "Source uncles" (MB) and "life children" (ZC) are thus in a well defined relationship of life. 
These two origin structures complement each other and are the basis for Buru social life. Their significance can be seen again in a case where the two concepts are conflated: the social position of an an tunin. This phrase literally means "original child" and refers to children born to women before they are married. Because an tunin are born before the hak anat of a woman has been transferred to another House and noro through marriage, these children belong to the natal hum lolin and noro of their mother and their mother's brother is their ama (F). They are "original children" because their source of life originates from the House to which they belong; their source of life and House are one and the same. In these cases the noro perpetuates itself internally rather than externally through the children of married women who have their source of life in another noro and House.

\section{References}

Fox, J.J.

1971 Sister's child as plant: metaphors in an idiom of consanguinity. In R. Needham (ed.) Rethinking kinship and marriage, pp.219-252. London: Tavistock.

1980a Introduction. In J.J. Fox (ed.) The flow of life: essays on Eastern Indonesia, pp.1-18. Cambridge, MA: Harvard University Press.

1980b Models and metaphors: comparative research in Eastern Indonesia. In J.J. Fox (ed.) The flow of life: essays on Eastern Indonesia, pp.327-333. Cambridge, MA: Harvard University Press.

1988 Origin, descent and precedence in the study of Austronesian societies. Public lecture in connection with De Wisselleerstoel Indonesische Studien, 17 March 1988, Leiden University.

1994 Reflections on "hierarchy" and "precedence". In M. Jolly and M. Mosko (eds) History and Anthropology. Transformations of hierarchy: structure, history and horizon in the Austronesian world, 7(1-4):87-108. Chur and Reading: Harwood Academic Publishers.

Fox, J.J. (ed.)

1980 The flow of life: essays on Eastern Indonesia. Cambridge, MA: Harvard University Press.

Grimes, B.D.

1990 The return of the bride: affiliation and alliance on Buru. MA thesis, The Australian National University.

Grimes, C.E.

1991 The Buru language of Eastern Indonesia. PhD dissertation, The Australian National University. 


\section{Grimes, C.E. and Kenneth R. Maryott}

1994 Named speech registers in Austronesian languages. In Tom Dutton and Darrell Tryon (eds) Language contact and change in the Austronesian world, pp.275-320. Berlin: Mouton de Gruyter.

Hocart, A.M.

1952 The northern states of Fiji. London: The Royal Anthropological Institute of Great Britain and Ireland Occasional Publication No. 11.

Keesing, R.M.

1975 Kin groups and social structure. New York: Holt, Rinehart, and Winston.

Traube, E.

1987 Obligations to the source: complementarity and hierarchy in an eastern Indonesian society. In D. Maybury-Lewis and U. Almagor (eds) The attraction of opposites: thought and society in a dualistic mode. Ann Arbor: University of Michigan Press.

\section{Notes}

${ }^{1}$ See Fox $(1971,1980,1988)$ and Traube (1987) for discussions of concepts similar to Buru lahin in other eastern Indonesian languages. In many of these languages this "origin" concept is expressed by a word cognate with Proto-Austronesian * puqun ("tree") (cf. also Fox 1988:14). Following regular historical sound changes this protoform appears in Buru as puun, but with a slight semantic shift, referring to plants which are more along the lines of what would be called a bush or shrub in English, rather than tree. The Buru word lahin is thus not cognate with * puqun, but is very similar semantically to both botanical and metaphorical meanings associated with regional cognates of * puqun.

2 This segment of Buru society, the indigenous people living in the interior of the island, was the main focus of the research upon which this paper is based. The research was carried out under a cooperative agreement between Pattimura University in Ambon and the Summer Institute of Linguistics under the auspices of the Indonesian Department of Education and Culture during 1985-1991.

3 Buru ideas regarding affiliation are discussed more fully in B.D. Grimes (1990).

4 The phrase "origin structure" comes from Fox (1988) where he used it to refer to similar Rotinese epistomological ideas about origin and cause.

${ }^{5}$ Fam is an Ambonese Malay word of Dutch origin and is used throughout parts of Maluku to refer to various types of kin groups. 